\title{
Proposal of a Mechanism for Setting Bogie Wheelsets to Radial Position while Riding Along Track Curve
}

Vladimír Hauser, Olena S. Nozhenko, Kateryna O. Kravchenko, Mária Loulová, Juraj Gerlici, Tomáš Lack Faculty of Mechanical Engineering, University of Zilina, Univerzitná 8215/1, 01026 Žilina. Slovak Republic. E-mail: vladimir.hauser@fstroj.uniza.sk,_ olena.nozhenko@fstroj.uniza.sk,_kateryna.kravchenko@fstroj.uniza.sk, maria.loulova@fstroj.uniza.sk, juraj.gerlici@fstroj.uniza.sk, tomas.lack@fstroj.uniza.sk

Passing of vehicles along curved track is a serious technical problem, which needs special attention. It is especially actual in the environment of urban lines, where it is necessary to pass a track of small radius. There is a significant strain of track as well as tram's bogies. It results in excessive wear in rail-wheel contact. Considerable is also the noise caused by operation on such track. Behavior of the vehicle when riding along track curve is influenced by the wheelset guidance design. If the wheelset guidance is able to set the wheelsets in track curve to a radial position, mitigation of the negative phenomenon can be expected. This paper deals with a design of a mechanism for setting wheelsets in a track curve to a radial position for tram cars. Dynamical analysis of a simplified tram car model was performed. Courses of monitored values of bogie with and without designed mechanism are compared.

Keywords: wheelset steering mechanism, simulation analysis, creep velocities in wheel - rail contact.

\section{Acknowledgement}

This paper was created after the processing of the project "RAILBCOT - RAIL Vehicles Brake COmponents Test Stand", ITMS Code 26220220011 based on the support of Research and Development Operational Program financed by European Fund of a Regional Development. The work was also supported by the project No. APVV-0842-11: "Equivalent railway operation load simulator on the roller rig".

Research-Educational Center of Rail Vehicles (Výskumno-vzdelávacie centrum kol’ajových vozidiel)

\section{References}

[1] BLATNICKÝ, M., DIŽO, J., TIMOŠČUK, M. (2016) Design of a three-finger robot manipulator. In: Manufacturing technology: journal for science, research and production. - ISSN 1213-2489. - Vol. 16, no. 3 (2016), s. 485-489.

[2] DIŽO, J. (2016) Analysis of a goods wagon running on a railway test track. In: Manufacturing technology : journal for science, research and production. - ISSN 1213-2489. - Vol. 16, no. 4 (2016), s. 667-672.

[3] GERLICI, J., LACK, T., HAUSER, V., MAŇUROVÁ, M., NOZHENKO, O., S., KRAVCHENKO, K., O. (2016) The Wagon Bogie. Utility model application no. u 2016 09015. Classification B61F5/30. State enterprise "Ukrainian intellectual property institute" (UKRPATENT). Street Glazunova 1, 01601, Kijev 42. http://www.uipv.org /en/index.html, Registered on 2016/08/25.

[4] HAUSER, V. (2016). Effects of T3 tram bogie to the track when passing transition curves. In: Experimental and computational methods in engineering. Conference proceedings of the III. International scientific conference. 2016 jun 2.-3., Ústí nad Labem. ISBN 978-80-7561-004-1.

[5] HAUSER, V. (2016) Mitigate the effects of tram bogie transit on a track in a curve. In: Experimental and computational methods in engineering. Conference proceedings of the III. International scientific conference. 2016 jun 2.-3., Ústí nad Labem. ISBN 978-80-7561-004-1.

[6] HAUSER, V. (2015) Running of public transport vehicles through small radius track. In: Current problems in rail vehicles PRORAIL 2015, Proceedings of lectures, Žilina, 16.-18.9.2015, Slovak Republic, ISBN 978-80-8927648-6. - S. 199-206.

[7] POLACH, P.: (2015). Influene of the Shock Absorbers Type Change at Stress of the Trolleybus Chassis. In: Manufacturing technology. Vol. 15, No. 1, 2015. Pp. 77 - 86. ISSN 1213-2489

[8] SIMPACK A.G. (2016). Documentation to the program system SIMPACK.

[9] SUCHÁNEK, A., HARUŠINEC, J. (2015). The downhill braked railway wheel structural analysis by means of the ANSYS multiphysics program system package. In: Manufacturing technology : journal for science, research and production. - ISSN 1213-2489. - Vol. 15, no. 5 (2015), s. 945-950.

[10] SVOBODA, M., SOUKUP, J. (2013). Dynamic measurement of four-axle railway wagon. In: Manufacturing Technology. 2013, vol. 13, iss. 4, (pp. 552-558). ISSN 1213-2489. 